\title{
Red Cell-sensitizing Antigens of Lactobacilli
}

\author{
By MARY MCLOUGHLIN AND F. S. STEWART \\ The Department of Bacteriology, Trinity College, Dublin, Ireland
}

(Accepted 2 April 1971)

\begin{abstract}
SUMMARY
Three serologically distinct red cell-sensitizing antigens were identified in lactobacilli. Two possessed the serological specificity of the streptococcal Hickey (polyglycerophosphate) and 44 sensitizing antigens. All resembled the streptococcal antigens in physical properties and in being excreted, sometimes in considerable amount. They were extracted from intact bacteria by a variety of procedures and were thought to have an intramural location. The Hickey antigen was present in sufficient concentration on the cell wall surface of certain strains to take part in bacterial agglutination reactions. The relationship of sensitizing antigen distribution to various taxonomic parameters of the lactobacilli is considered.
\end{abstract}

\section{INTRODUCTION}

The production by streptococci of a number of serologically distinct red cell-sensitizing antigens has been described previously (Stewart, Steele \& Martin, I959; Stewart, I963, 1965; Stewart \& McLoughlin, 1965). The serological specificity of one of these antigens, the Hickey antigen, was attributed to polyglycerophosphate haptenic groups (Stewart, I96I; Jackson \& Moskowitz, I966). The Hickey antigen has a distribution paralleling that of the non-species specific polyglycerophosphate precipitating antigen described by McCarty (I959) and the non-species specific red cell-sensitizing antigen described by Rantz, Randall \& Zuckerman (1956). It is, probably, a glycerol teichoic acid.

The lactobacilli are closely related to streptococci and contain glycerol teichoic acids as integral cell components (Baddiley \& Davison, 196I). It was, therefore, of interest to investigate the production of sensitizing antigens by lactobacilli and to examine the relationship of these to the streptococcal-sensitizing antigens previously defined (Stewart, Steele \& Martin, 1959; Stewart, 1963, 1965; Stewart \& McLoughlin, 1965). The occurrence of red cell-sensitizing antigens in cell-wall preparations of lactobacilli has been described by Chung \& Hawirko (I962) using tanned sheep red cells which adsorb protein as well as polysaccharide antigens, and more recently by Hewett, Knox \& Wicken (1970) using untreated sheep red cells. The precise number of antigens involved in these studies and their relationship to the streptococcal-sensitizing antigens already identified was not determined.

\section{METHODS}

Organisms. Fifty-one strains of lactobacilli were examined. Sources were: The National Institute for Research in Dairying, Reading, Berkshire (six strains); Guinness Research Laboratories, Dublin (two strains); the Department of Pathology, Trinity College, Dublin (two strains). One strain had been isolated in our own laboratory from cheese. The remaining strains were isolated from various human sources: stools, rectal swabs, carious teeth and urine. 
The organisms were identified according to Sharpe (1962) as follows: Lactobacillus acidophilus (34 strains), L. salivarius (one strain), L. leichmanii (one strain), L. casei (five strains), L. plantarum (two strains), L. fermenti (seven strains), L. brevis (one strain).

Production and extraction of sensitizing antigens. The organisms were grown in $0.5 \%(\mathrm{w} / \mathrm{v})$ glucose digest broth for $48 \mathrm{~h}$. at $37^{\circ}$. The definitive tests for antigenic content were performed on saline extracts obtained by autoclaving suspensions of intact organisms at $115^{\circ}$ for 20 min. These suspensions were prepared by resuspending the deposits obtained by centrifugation of glucose digest broth cultures in 0.01 of the original volume of saline. Acid extracts were prepared as previously described (Roberts \& Stewart, 196I). Phosphate extracts were prepared by boiling in 0.13 M-sodium phosphate buffer at $\mathrm{pH} 7$ for $\mathrm{IO}$ min. Trichloracetic acid extracts were prepared following the procedure of Davison \& Baddiley (1963). Subcellular fractions were prepared as previously described (Stewart \& McLoughlin, 1965).

Demonstration of sensitizing antigens. The procedures employed for red cell sensitization, haemagglutination tests, antibody absorption and antigen titration, were as described previously (Stewart, 1963; Stewart \& McLoughlin, 1968). The antisera employed for the detection of streptococcal-sensitizing antigens were as follows: Commercial (Burroughs Wellcome, London, N.W. I group C, group D and group O antisera were used for the detection of the Hickey, $D^{\prime}$ and 8029 antigens respectively (Stewart \& McLoughlin, I968; Stewart \& McLoughlin, 1965; Stewart, 1965). The group C sera were absorbed with red cells treated with the supernatant fraction of a digest broth culture of the Hickey-negative viridans 63 Streptococcus. The group $\mathrm{D}$ antiserum was absorbed with a deposit of a group $\mathrm{K}$ strain 44 which produced both Hickey and 44 antigens. Rabbit antiserum prepared by immunization with the Hickey 44 positive group K strain 44 and absorbed with deposit of the Streptococcus pyogenes strain Hickey was used for the detection of the 44 antigen. Rabbit antiserum prepared by immunization with the viridans Streptococcus strain 63 was used for the detection of the 63 antigen. The antiserum used for detection of the Mahon antigen was obtained from a patient with subacute bacterial endocarditis from whose blood this strain had been recovered (Stewart et al. 1959). Antiserum to the streptococcal antigen Weir, an antigen which had been identified in only one of a large number of strains of streptococci previously examined (Stewart, Steele \& Martin, 1959), was not available for haemagglutination tests. The antiserum originally employed for the detection of this antigen was derived from a patient with subacute bacterial endocarditis. It had not proved possible to prepare an immune serum of similar specificity by rabbit immunization.

Enzyme treatment. A standard procedure was employed for treating antigen-containing extracts with enzymes. One vol. antigen preparation and I vol. appropriate enzyme buffer solution were incubated I h. at $37^{\circ}$, then boiled for 10 min. Controls using enzyme buffer solutions inactivated by boiling were set up at the same time. The enzyme preparations used were: trypsin, $0.1 \%$ (w/v) crystalline trypsin (British Drug Houses Ltd, Poole, Dorset) in 0.13 M-phosphate buffer at $\mathrm{pH} 8$; papain, Low's papain solution as described in Race \& Sanger (1955); lipase, I \% (w/v) wheat germ lipase (British Drug Houses Ltd) in $0.13 \mathrm{M}-$ phosphate buffer at $\mathrm{pH} 7$.

Cell wall analyses. Subcellular fractions were prepared and sugars were extracted from cell walls by the techniques of Roberts \& Stewart (I96I). Sugars were identified by thinlayer chromatography as described by Baron \& Economidis (I963). Glycerol and ribitol teichoic acids were extracted and identified by the procedures of Baddiley \& Davison (196I) and Davison \& Baddiley (1963) except that glycerol and ribitol as end products of hydrolysis were separated by thin-layer chromatography. 
Bacterial agglutination. Washed deposits from $0.5 \%(\mathrm{w} / \mathrm{v})$ glucose digest broth cultures were resuspended in saline to an opacity matching that of tube 4 of Brown's opacity tubes (Burroughs Wellcome). Serial twofold dilutions of serum were made, starting with a I:20 dilution, and 5 drops of serum dilution and 5 drops of bacterial suspension delivered from Pasteur pipettes, discharging 30 drops per ml., were mixed and incubated for $2 \mathrm{~h}$. at $37^{\circ}$ in Kahn-type tubes, after which they were allowed to stand overnight at $4^{\circ}$. The mixtures were then read by examination of the sedimented bacteria in a magnifying mirror.

Miscellaneous. Gel filtrations on Sephadex G-200 and starch-block electrophoresis were carried out by methods previously described (Stewart \& McLoughlin, 1965).

\section{RESULTS}

Antibody content of Lactobacillus antisera. Antisera were prepared by rabbit immunization against eight strains of Lactobacillus. Only five of these showed a satisfactory antibody level against red cells treated with saline extract of the corresponding strain. These were sera prepared against three strains of Lactobacillus acidophilus and two strains of $L$. casei. From the results of absorption tests with a Hickey-positive group C Streptococcus, it was apparent that all five of these antisera contained antibody to the Hickey antigen. Antibody to the Streptococcus antigen 44 was not found in any of the sera, two of which had been prepared against strains which contained the 44 as well as the Hickey antigen. One serum after absorption with Hickey 44-positive Streptococcus strain 44 (group K) still contained antibody for organisms treated with extract of the homologous $L$. acidophilus strain McGee (Table I). The McGee antigen was not found in saline extracts of any of 23 strains of

\section{Table r. Absorption of haemagglutinating antibodies from two Lactobacillus acidophilus antisera}

A I : Io dilution of antiserum was absorbed with centrifuged deposit from a glucose digest broth culture of the absorbing strain and titrated, absorbed and unabsorbed, against red cells sensitized with saline extracts of each of the test strains.

\begin{tabular}{|c|c|c|c|c|c|}
\hline \multirow[b]{2}{*}{ Serum } & \multirow{2}{*}{ Absorbing strain } & \multicolumn{4}{|c|}{ Test strains } \\
\hline & & 6180 & 44 & McGee & Brady \\
\hline McGee & $\left\{\begin{array}{l}\text { Nil } \\
6180 \text { (group C) } \\
44 \text { (group K) }\end{array}\right.$ & $\begin{array}{r}640 \\
<\quad 10 \\
<10\end{array}$ & $\begin{array}{r}320 \\
<10 \\
<10\end{array}$ & $\begin{array}{r}320 \\
40 \\
160\end{array}$ & $\begin{array}{r}20 \\
<10 \\
<10\end{array}$ \\
\hline Brady & $\left\{\begin{array}{l}\text { Nil } \\
6180 \\
44\end{array}\right.$ & $\begin{aligned} & 160 \\
< & 10 \\
< & 10\end{aligned}$ & $\begin{aligned} & 80 \\
< & 10 \\
< & 10\end{aligned}$ & $\begin{array}{r}320 \\
<10 \\
<10\end{array}$ & $\begin{array}{r}40 \\
<10 \\
<10\end{array}$ \\
\hline
\end{tabular}

Titres are expressed as the reciprocal of the highest dilution causing haemagglutination.

streptococci or one strain of pneumococcus examined. The streptococcal strains comprised one representative of each of Lancefield groups, A, B, C, D, E, F, G, H, L, M, P, Q, four strains of group $\mathrm{O}$, two of group N, two of group K, one of the proposed 'group ' J' (Stewart \& McKeever, 1963) and the viridans strains 63 and Mahon.

Haemagglutination reactions of Lactobacillus extracts. Saline extracts of all the Lactobacillus strains were examined with antisera to the streptococcal antigens Hickey, 44, 63, D', 8029 and Mahon and also with McGee specific antiserum. All strains examined produced the Hickey antigen, 33 produced the Hickey and 44 antigens, and five the Hickey, 44 and McGee antigens. 
The relationship of antigen distribution to the Orla-Jensen (1919) taxonomic groups as defined by Sharpe (1962) is shown in Table 2. Lactobacillus acidophilus comprised strains showing all three haemagglutination types and contained all the McGee-positive strains. Lactobacillus fermenti strains included both Hickey-and Hickey + 44-positive haemagglutination types, while the strains of $L$. brevis, L. casei. L. leichmanii and L. plantarum produced only the Hickey antigen. The single strain of $L$. salivarius examined produced both the Hickey and 44 antigens. The McGee antigen (Table 2) was found only in the 44-positive strains and the 44 antigen only in Hickey-positive strains. No strains were encountered which produced only the 44 and/or McGee antigens.

\section{Table 2. Haemagglutination patterns of Orla-Jensen cultural groups of lactobacilli}

Red cells sensitized with saline extracts of each strain were tested with Hickey-, 44-, and McGeespecific antisera.

No. of antigenic types in each cultural group

Sensitizing antigen composi-

tion of strains
Hickey
Hickey +44
Hickey $+44+$ McGee

Thermo

Subgenus

Strains of Lactobacillus acidophilus, L. salivarius and L. leichmanii.

2 Strains of $L$. casei and L. plantarum. ${ }^{3}$ Strains of $L$. fermenti and $L$. brevis.

\section{Table 3. Sensitizing antigen titres of various Lactobacillus preparations}

For the preparation of saline extracts and subcellular fractions bacteria were resuspended to a concentration of 100 times that of original culture. Serial dilutions of these were used for sensitization of red cells which, after incubation, were tested for sensitizing antigens with Hickey-, 44- and McGee-specific antisera.

\begin{tabular}{|c|c|c|c|c|c|c|c|c|c|c|c|c|c|c|c|}
\hline \multirow[b]{2}{*}{ Strain } & \multicolumn{3}{|c|}{$\begin{array}{c}\text { Culture } \\
\text { supernatant }\end{array}$} & \multicolumn{3}{|c|}{$\begin{array}{l}\text { Saline } \\
\text { extract }\end{array}$} & \multicolumn{3}{|c|}{$\begin{array}{c}\text { Mickle } \\
\text { supernatant }\end{array}$} & \multicolumn{3}{|c|}{$\begin{array}{l}\text { Crude } \\
\text { cell wall }\end{array}$} & \multicolumn{3}{|c|}{$\begin{array}{l}\text { Trypsinized } \\
\text { cell wall }\end{array}$} \\
\hline & $\mathbf{H}$ & 44 & M & $\mathrm{H}$ & 44 & $\mathbf{M}$ & & 44 & & & 44 & & $\mathbf{H}$ & 44 & M \\
\hline & & 16 & I 6 & & 16 & 64 & & & & & 64 & & & & \\
\hline & 16 & 64 & I 6 & 16 & 256 & 64 & 1024 & 6,384 & & 256 & 1024 & 256 & I 6 & 64 & \\
\hline Colla & 4 & 4 & 4 & 4 & I 6 & I6 & 4 & 16 & 16 & 64 & 256 & I6 & 一 & - & - \\
\hline vW & 4 & I & 4 & 16 & I6 & 16 & 256 & 64 & I6 & 256 & 64 & 64 & - & - & \\
\hline
\end{tabular}

$\mathrm{H}=$ Hickey antigen; $\quad 44=44$ antigen; $\quad \mathrm{M}=$ McGee antigen.

Antigen titres are expresssed as highest dilution of antigen preparation giving positive haemagglutination reaction.

Localization of sensitizing antigens. As in the case of the streptococci, the sensitizing antigens of the lactobacilli were excreted, sometimes in considerable concentration, into the surrounding medium. In general, the extent of this excretion paralleled the amount of antigen extracted by autoclaving intact bacteria. All three antigens were found in considerable concentration in the supernatant fractions of crude walls after Mickle disintegration and high-speed centrifugation and in wall preparations purified by digestion with trypsin (Table 3). In general, the antigen concentrations in Mickle supernatant fractions and in crude wall preparations were appreciably higher than in saline extracts. In comparing these with the antigen concentrations in the supernatant fluids of broth cultures, the concentration of organisms used in the preparation of the saline extracts must be taken into account. It is then apparent that the amount of antigen excreted by the organisms was as great or 
greater than that recovered in saline extracts, Mickle supernatant fractions or crude walls. Trypsin treatment of the wall preparations resulted, as with the streptococci, in appreciable reduction in the titre of antigen demonstrable by haemagglutination. The results in Table 3 show also that the relative concentration of each of the antigens (as measured by the highest dilution of extract or culture supernatant fluid capable of sensitizing red cells to agglutination) varied in preparations obtained from different strains, confirming the serological distinctness of the different sensitizing antigens.

Properties of sensitizing antigens. The sensitizing antigens present in saline extracts of the McGee strain were resistant to digestion by papain and lipase but an approximately fourfold reduction in titre was found for each after digestion with trypsin. The antigens were not inactivated by treatment with $0.05 \mathrm{~N}-\mathrm{HCl}$ or $0.1 \mathrm{~N}-\mathrm{NaOH}$ for $30 \mathrm{~min}$. at $100^{\circ}$ or by exposure to $0.01 \mathrm{M}$-potassium periodate for $5 \mathrm{~min}$. at room temperature. They possessed a high order of heat stability, the antigens in culture supernatant fluids of five McGeepositive strains being unaffected by exposure to 1 I $5^{\circ}$ for $20 \mathrm{~min}$. On gel filtration of saline extracts on Sephadex G-200 (the McGee strain, one Hickey-positive strain and one Hickey + 44-positive strain) the antigens appeared just after the void volume. The antigens in a McGee saline extract and culture supernatant fluid were both freely filtrable through an Oxoid 'Standard' membrane filter.

On gel filtration of McGee saline extract, antigen capable of precipitating with homologous serum but not capable of sensitizing red cells appeared in the later fractions and was, therefore, of lower molecular weight than the sensitizing antigens. Some separation of the precipitating from the sensitizing antigens of this strain was obtained by starch-block electrophoresis; the precipitating antigen showed slightly greater mobility towards the anode than the sensitizing antigens. The precipitating and sensitizing antigens of the McGee strain were also separated by ethanol fractionation, the bulk of the sensitizing antigens being precipitated at an ethanol concentration of $33 \%(\mathrm{v} / \mathrm{v})$ and the precipitating antigen maximally (as indicated by the strength of the precipitin reaction) at an ethanol concentration of 66 to $90 \%(\mathrm{v} / \mathrm{v})$. No significant separation of the Hickey-, 44- and McGee-sensitizing components was achieved by any of these procedures.

Comparison of extraction procedures. As a procedure for extracting antigen from intact cells, autoclaving in saline was compared with extraction in phosphate buffer at $\mathrm{pH} 8$ for 10 min. at $100^{\circ}$, in $0.05 \mathrm{~N}-\mathrm{HCl}$ for $10 \mathrm{~min}$. at $100^{\circ}$ and by the trichloracetic acid extraction procedure used by Davison \& Baddiley (1963) for teichoic acids. Trichloracetic acid extraction yielded titres of sensitizing antigen similar to those obtained by saline extraction. The titres obtained by $\mathrm{HCl}$ and phosphate buffer extraction were, however, somewhat lower. As trichloracetic acid is commonly used for extraction of glycerol teichoic acids, the capacity of extracted organisms to absorb the Hickey antibody was tested. It was considerably reduced. On the other hand, organisms subjected to nine successive autoclavings in saline showed no obvious impairment of adsorbing capacity. The loose association of the sensitizing antigen with intact bacteria was revealed by the appreciable amount of antigen recovered in the washings of organisms which had been incubated at $37^{\circ}$ for $2 \mathrm{~h}$. in saline.

Analysis of subcellular fractions. Subcellular fractions of io strains were examined by thin-layer chromatography. The cell walls and supernatant fractions obtained by Mickle disintegration and high-speed centrifugation were examined for the presence of glycerol and ribitol teichoic acids. The cell walls were also examined for the presence of glucose, galactose and rhamnose. The results (Table 4) showed that, like streptococci (Roberts \& Stewart, 196I), all strains possessed glucose as a wall component and were heterogeneous in respect of their content of galactose and rhamnose. Glycerol teichoic acid was identified 
in the Mickle supernatant fractions of all strains examined but was not identified in the cell walls of three strains of Lactobacillus casei and one strain of L. plantarum. Some trypsinized cell wall preparations were titrated for sensitizing antigen content. Surprisingly the walls of two strains of $L$. casei (C 5 and C6) in which glycerol teichoic acid was not detected gave titres for the Hickey antigen of I/I024 while the walls of two L. acidophilus strains in which glycerol teichoic acid was detected gave Hickey titres of only $\mathrm{I} / \mathrm{I} 6$.

Table 4. Subcellular composition in relation to haemagglutination pattern

\begin{tabular}{|c|c|c|c|c|c|c|c|}
\hline \multirow{3}{*}{$\begin{array}{l}\text { Species of } \\
\text { Lactobacillus }\end{array}$} & \multirow[b]{3}{*}{ Strain } & & & & \multicolumn{2}{|c|}{ Teichoic acids } & \multirow{3}{*}{$\begin{array}{l}\text { Haemagglutina- } \\
\text { tion type }\end{array}$} \\
\hline & & \multicolumn{3}{|c|}{ Cell wall sugars* } & \multirow{2}{*}{$\begin{array}{l}\text { Mickle } \\
\text { super- } \\
\text { natant }\end{array}$} & \multirow{2}{*}{$\begin{array}{c}\text { Cell } \\
\text { walls }\end{array}$} & \\
\hline & & Glu & Gal & $\mathrm{Rh}$ & & & \\
\hline L. acidophilus & MCGEE & + & - & Trace & $\mathrm{G}$ & $\mathrm{G}$ & $\mathrm{H}+44+\mathrm{M}$ \\
\hline L. acidophilus & GALLAGHER II & + & - & - & $\mathrm{G}$ & $\mathrm{G}$ & $\mathrm{H}$ \\
\hline L. acidophilus & SMITH & + & - & + & $\mathrm{G}$ & $\mathrm{G}$ & $\mathrm{H}+44+\mathrm{M}$ \\
\hline L. casei & PATH & + & - & + & $G$ & - & $\mathrm{H}$ \\
\hline L. casei & $\mathrm{C}_{5}$ & + & - & + & $G$ & - & $\mathrm{H}$ \\
\hline L. casei & $c 6$ & + & - & + & $\mathrm{G}$ & - & $\mathbf{H}$ \\
\hline L. plantarum & $G$ & + & - & - & $\mathrm{G}$ & $\mathrm{G}, \mathrm{R}$ & $\mathbf{H}$ \\
\hline L. plantarum & $\mathrm{s}$ & + & - & + & $\mathrm{G}$ & $\mathrm{R}$ & $\mathbf{H}$ \\
\hline L. fermenti & RS2 & + & + & - & $\mathrm{G}$ & $\mathrm{G}$ & $\mathrm{H}$ \\
\hline L. fermenti & s & + & + & - & $G$ & $\mathrm{G}$ & $\mathrm{H}$ \\
\hline
\end{tabular}

* Walls were examined only for the presence of glucose (Glu), galactose (Gal) and rhamnose (Rh). $\mathrm{G}=$ glycerol teichoic acid; $\mathbf{R}=$ ribitol teichoic acid; $\mathbf{H}=$ Hickey.

\section{Table 5. Absorption of haemagglutinating antibodies from pooled normal human serum}

Undiluted serum was absorbed with centrifuged deposit from a glucose digest broth culture of the absorbing strain and titrated, absorbed and unabsorbed against red cells sensitized with saline extracts of each of the test strains.

\begin{tabular}{|c|c|c|c|c|}
\hline Absorbing strain & HA type & McGee & 6180 & 44 \\
\hline Nil & & 8 & 8 & 8 \\
\hline Streptococcus 6180 & Hickey & 8 & $<$ I & 8 \\
\hline Streptococcus 44 & Hickey +44 & 8 & $<\mathrm{I}$ & $<\mathrm{I}$ \\
\hline Lactobacillus MCGEE & Hickey $+44+$ McGee & $<$ I & $<\mathrm{I}$ & $<\mathrm{I}$ \\
\hline
\end{tabular}

Titres are expressed as the reciprocal of the highest serum dilution causing haemagglutination.

Reactions with normal human serum. As with streptococcal red cell-sensitizing antigens, red cells sensitized by Lactobacillus antigens were agglutinable by normal human serum. To clarify the nature of the antibodies present, a pool of normal human serum was absorbed with deposit of the Hickey-positive group C Streptococcus NCTC 6I8o. This removed all antibody for the sensitizing antigen of strain 6180 but did not affect the antibody titre of the serum against red cells sensitized with saline extract of strain 44 (Table 5). From these results it was apparent that the serum contained antibody to both Hickey- and 44-sensitizing antigens. That the serum also contained antibody to the McGee-sensitizing antigen was shown by absorption of the serum with deposit of the 44 strain. The removal of all antibody for red cells sensitized with 44 saline extract did not affect the titre of the serum against red cells sensitized with saline extract of the McGee strain.

The sensitizing antigens of the McGee strain were like streptococcal-sensitizing antigens, susceptible to inhibition by the non-antibody inhibitor of normal human serum. This 
inhibition was demonstrated for all three antigens in tests against a pool of normal human serum and also against the supernatant fraction of boiled, diluted human serum concentrated by dialysis against Carbowax 6000 (Stewart \& McLoughlin, 1968). The concentrated supernatant fraction of the boiled serum, however, possessed only about $\mathrm{I} / 2$ oth of the inhibitory activity of unheated serum.

Bacterial agglutination. The capacity of all eight of the Lactobacillus antisera to agglutinate suspensions of intact bacterial cells was investigated. Only 12 strains yielded suspensions sufficiently stable for use as antigens in agglutination tests. In screening tests carried out with a single ( $1 / 20$ ) dilution of antiserum, each of the antisera possessed agglutinins for a number of the strains. From the pattern of reactions obtained it was apparent that the strains could be arranged in an order of agglutinability in respect of the number of sera by which they were agglutinable and that some of the antisera were more actively agglutinating than others. The distribution of reactions obtained and their relative strength suggested that the agglutination patterns were determined by some major antigen or antigens widely distributed throughout the group.

\section{Table 6. Haemagglutination and bacterial agglutination reactions of an anti- serum prepared against a strain of Lactobacillus casei (Path)}

Haemagglutination titres were determined against red cells sensitized with the appropriate saline extract, and bacterial agglutination titres by a tube method against bacterial suspensions prepared from glucose digest broth cultures. The antiserum was absorbed by resuspending centrifuged bacterial cells in a $\mathrm{I}: 20$ dilution of serum, the serum being separated by centrifugation from the mixture after standing for $\mathrm{I} h$. at room temperature.

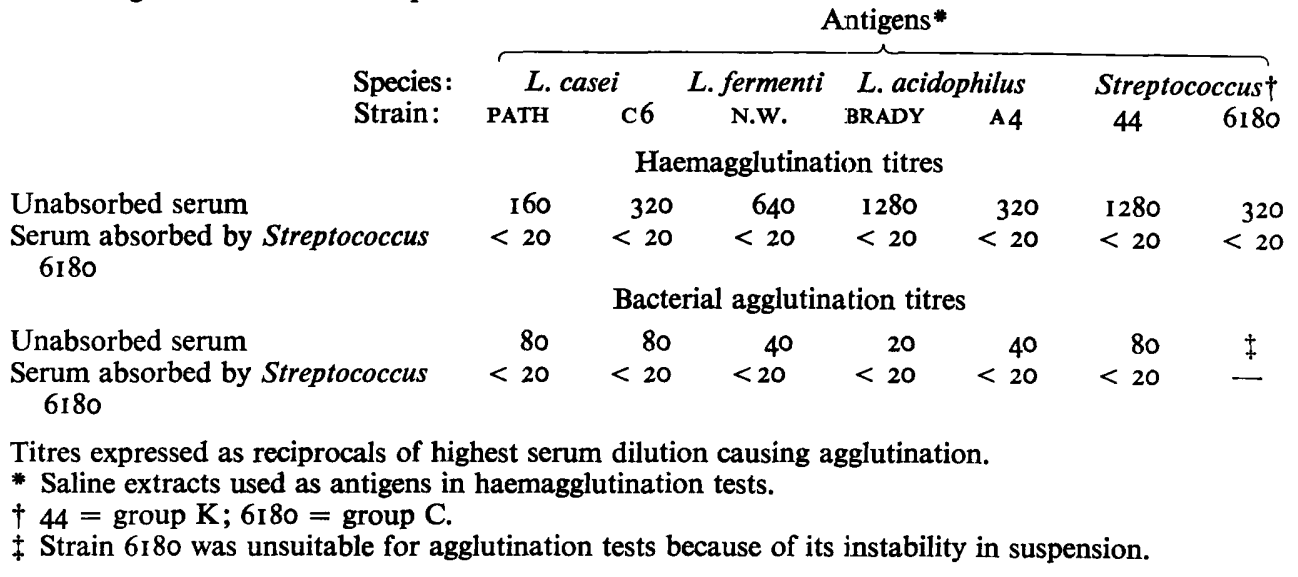

The antiserum giving the strongest reactions was one prepared against a strain of Lactobacillus casei (Table 6). Although there was no clear correlation between the bacterial agglutination and haemagglutination titres of the antiserum for the various strains, both the haemagglutinating and bacterial agglutinating antibodies could be removed by absorption with the Hickey-positive group C Streptococcus NCTC 6I80. The Lactobacillus antiserum also agglutinated the Streptococcus strain 44. From these results it seemed likely that the Hickey antigen was involved in bacterial agglutination by this antiserum. In agreement with this was the finding that three out of five of the more highly agglutinable strains of lactobacilli were also agglutinated by a group $\mathrm{C}$ streptococcal antiserum containing antibody specific for the Hickey antigen. This serum did not, however, agglutinate strain 44 .

As suspensions of cell walls prepared by Mickle disintegration were uniformly unstable they were unsuitable for agglutination tests. 


\section{DISCUSSION}

Lactobacilli produce red cell-sensitizing antigens. Three such antigens, heat stable and capable of sensitizing untreated human red cells resemble the sensitizing antigens produced by the streptococci in their physical properties. Two possessed the serological specificity of the streptococcal Hickey and 44 antigens, the Hickey antigen being produced by all strains examined.

Although a specific pattern of sensitizing antigens was not found for each of the OrlaJensen cultural groups of lactobacilli, there was some correlation between cultural group and antigen distribution. Thus the majority of Thermobacterium strains produced the 44 as well as the Hickey antigen. The McGee antigen was confined entirely to this group. Neither the 44 nor the McGee antigens were identified in extracts of any of the Streptobacterium strains. The Betabacterium strains occupied an intermediate position as some strains produced the 44 as well as the Hickey antigen but not the McGee antigen.

When the strains are grouped on the basis of DNA guanine + cytosine content as determined by Gasser \& Mandel (I968) a similar correlation is observed. These workers define three groups of strains with a range of guanine + cytosine content in moles \% as follows: (I) 33 to 37.9 ; (2) 42 to 47 ; (3) 47 to 53 . Of the strains examined, Lactobacillus acidophilus and $L$. salivarius would, on the basis of Gasser \& Mandel's figures, be assigned to the first group, L. brevis, L. casei and L. plantarum to the second group, and $L$. leichmanii, and $L$. fermenti to the third group. The 'Hickey only' type strains for each of these groups would on this basis be (I) 5 out of 35 , (2) 8 out of 8 , (3) 5 out of 8 . In antigenic composition the group 3 strains which have the highest guanine + cytosine content are intermediate between those of groups I and 2 .

Heterogeneity in respect of sensitizing antigen composition occurs also at species level, the Lactobacillus acidophilus strains exhibiting all three antigenic types and the L. fermenti strains showing both the Hickey only and the Hickey +44 type. Within these two species, therefore, the sensitizing antigens should be of some value as strain markers.

The Hickey antigen was present in wall preparations of strains in which glycerol was not identified in concentrations at least as high as in the walls of strains in which glycerol was identified. This suggests that sensitizing antigen accounts for only a fraction of the teichoic acid content of glycerol-positive strains. Assuming that the identification of the Hickey antigen as a glycerol teichoic acid is correct, this would also imply that the glycerol teichoic acid must have been present in minute amounts (undetectable by the analytical procedure employed) in the cell walls of the glycerol-negative strains.

Like streptococci (Roberts \& Stewart, 196I) lactobacilli are heterogeneous in respect of wall rhamnose composition. Unlike streptococci, however, there was no significant correlation between the distribution of rhamnose and that of the Hickey antigen. It was of interest, however, that rhamnose was present in the walls of the four strains in which glycerol teichoic acid was not identified.

As regards their location, the sensitizing antigens clearly have some association with the wall. In the case of the streptococci Stewart (1963) proposed that they occur as the intramural cementing substance, possibly in the interstices of the wall peptidoglycan. Their occurrence in the Mickle supernatant fractions of lactobacilli is consistent with a similar location in these organisms. The finding that the Hickey antigen appears to participate in agglutination reactions, which agrees with a report by Mills (I969) for glycerol teichoic acid in Lactobacillus jugurti, indicates that a considerable amount of the antigen is present on 
the surface of the cell. Either an intramural and/or surface location would explain the ready excretion of the antigens.

The finding that the Streptococcus strain 44, although agglutinated by a Lactobacillus casei antiserum containing Hickey antibody, was not agglutinated by streptococcal antiserum also containing Hickey antibody has not been explained. It might be due to differences in the accessibility to antibody of the Hickey antigen on the surfaces of the two strains. Thus the determinant groups of the antigens on the $L$. casei strain might be more accessible than the determinant groups of the antigen on the Streptococcus strain. If the reactive surface of the Hickey antibody in the Lactobacillus antiserum were more extensive than the reactive surface of the Hickey antibody in the streptococcal antiserum, then the former but not the latter might be capable of effective contact with the streptococcal antigen. Alternatively it is possible that the antibody produced in response to the Lactobacillus antigen might be a more effective agglutinating antibody (possibly IgM) than that produced in response to the streptococcal antigen.

Whether the different sensitizing antigens exist (in strains in which they occur) as separate molecular entities or as different determinants on the same molecule has not been determined. The failure to separate the different antigenic specificities by any of the physical or inactivating procedures employed in the present work favours the latter interpretation. In this case, although the relative titres of the different antigens might vary, the titres of the 44 and/or McGee antigens would never exceed those of the Hickey polyglycerophosphate antigen, of which there should be at least as many determinants per molecule as of the other two. For two of the strains examined, however, the 44 antigen titre was appreciably higher than the Hickey titre, suggesting that in these strains the presence of 44 determinants masks the reactivity of the Hickey determinants. This would resemble the masking of polyglycerophosphate determinants by D-alanine residues found by McCarty (1964) for a streptococcal teichoic acid and the masking, also shown by McCarty (1956), of rhamnose determinants by $\mathrm{N}$-acetyl glucosamine residues in group A variant streptococcal polysaccharide. On the evidence available it is not possible to choose between these two explanations.

The gel filtration results indicate that the sensitizing antigen determinants are associated with molecules of much greater molecular weight than that of about 12,000 derived by Jackson \& Moskowitz (1966) on the basis of the amount of phosphate liberated from a streptococcal teichoic acid by an Escherichia coli phosphatase. Their large molecular weight would be consistent with the presence of a considerable amount of lipid which might be responsible for their adsorption to red cells as suggested by Hewett et al. (1970).

In view of their macromolecular dimensions, the failure of preparations of sensitizing antigens to give positive precipitin reactions is of interest. This could be explained by the high sensitivity of the passive haemagglutination technique as a serological procedure, which would also explain why the Hickey antigen was demonstrable in considerable amounts in wall preparations of strains of Lactobacillus casei in which it had not been possible to demonstrate the presence of glycerol teichoic acid by chemical methods. This latter finding also implies that much of the glycerol teichoic acid extractable from lactobacilli does not sensitize red cells. This agrees with the failure of the group precipitating antigen of group D streptococci, which has been identified as a glycerol teichoic acid, to sensitize red cells (Stewart \& McLoughlin, 1965). 
We are indebted to the Medical Research Council of Ireland for its financial support to Dr W. S. L. Roberts for his invaluable advice on cell wall analysis, and to Miss M. Monaghan for technical assistance.

\section{REFERENCES}

Baddiley, J. \& Davison, A. L. (I96I). The occurrence and location of teichoic acids in lactobacilli. Journa l of General Microbiology 24, 295-299.

Baron, D. N. \& EConomidis, J. (1963). Thin-layer chromatography for amino acids and sugars. Journal of Clinical Pathology 16, 484-486.

ChUNG, K. L. \& HawiRko, R. Z. (1962). A serological study of cell walls of certain lactic acid bacteria. Canadian Journal of Microbiology 8, 629-637.

DAvison, A. L. \& BADDILEY, J. (1963). The distribution of teichoic acids in staphylococci. Journal of General Microbiology 32, 271-276.

Gasser, F. \& MANDEL, M. (1968). Deoxyribonucleic acid base composition of the genus Lactobacillus. Journal of Bacteriology 96, 580-588.

Hewett, M. J., Knox, K. W. \& Wicken, A. J. (1970). Studies on the group F antigen of lactobacilli: Detection of antibodies by haemagglutination. Journal of General Microbiology 6o, 315-322.

JACkson, R. W. \& Moskowitz, M. (1966). Nature of a red cell-sensitizing substance from streptococci. Journal of Bacteriology 91, 2205-2209.

MCCARTY, M. (1956). Variation in the group specific carbohydrate of group A streptococci. Journal of Experimental Medicine 104, 629-643.

MCCARTY, M. (1959). Bacterial polyglycerophosphate. Journal of Experimental Medicine rog, 361-378.

MCCARTY, M. (I964). The role of D-alanine in the serological specificity of group A streptococcal glycerol teichoic acid. Proceedings of the National Academy of Sciences of the United States of America 52, 259-265.

MiLls, C. K. (1969). Agglutinating antigens of Lactobacillus jugurti ATCC521. Journal of General Microbiology 57, $105-114$.

Orla-Jensen (19I9). cited by Sharpe, M. E., Fryer, T. F. \& Smith, D. G. (1966). In Identification Methods for Microbiologists, Part A, pp. 72-79. London \& New York: Academic Press.

RaCE, R. R. \& Sanger, R. (1955). Blood Groups in Man, 3rd edn, p. 252. Oxford: Blackwell Scientific Publications.

Rantz, L. A., Randall, E. \& Zuckerman, A. (1956). Haemolysis and haemagglutination in normal and immune serums of erythrocytes treated with a non-species-specific bacterial substance. Journal of Infectious Diseases 98, 21 I-222.

RoBerts, W. S. L. \& StewART, F. S. (I961). The sugar composition of streptococcal cell walls and its relation to haemagglutination pattern. Journal of General Microbiology 24, 253-260.

Sharpe, M. E. (1962). Taxonomy of the lactobacilli. Dairy Science Abstracts 24, 109-118.

StEWART, F. S. (196I). Bacterial polyglycerophosphate. Nature, London 190, 464.

STEWART, F.S. (1963). Identification of a new streptococcal red cell-sensitizing antigen. Immunology 6, 403-4II.

STEWART, F. S. (1965). Streptococcal red cell-sensitizing antigens. Nature, London 206, 202.

StewART, F. S. \& MCKeEver, J. D. (1963). Serological definition of Lancefield group K. Journal of Pathology and Bacteriology 85, 383-388.

Stewart, F. S. \& MCLoughlin, M. (I965). A red cell-sensitizing antigen of group D streptococci. Immunology 9, 319-326.

Stewart, F. S. \& McLoughlin, M. (1968). Serum inhibitor for bacterial red cell-sensitizing antigens. Immunology 15, 13-22.

Stewart, F. S., Steele, T. W. \& Martin, W. T. (I959). The mechanisms involved in the production of red cell-panagglutinability by streptococcal cultures. Immunology 2, 285-294. 